\title{
Polyacrylamide Gel Electrophoresis
}

National Cancer Institute

\section{Source}

National Cancer Institute. Polyacrylamide Gel Electrophoresis. NCI Thesaurus. Code C16539.

Analytical and separative procedures in which molecules, particularly proteins or nucleic acids, are separated by their different electrophoretic mobilities in a hydrated gel. The gel suppresses convective mixing of the fluid phase through which the electrophoresis takes place and contributes molecular sieving. For proteins, commonly carried out in the presence of the anionic detergent sodium dodecylsulphate (SDS). SDS denatures proteins so that noncovalently associating sub unit polypeptides migrate independently and by binding to the proteins confers a net neg ative charge roughly proportional to the chain weight. 